\title{
The Effect of Principal Leadership and Satisfaction on the Teachers' Performance
}

\author{
Arnilayeti $^{1 *}$, Happy Fitria ${ }^{2}$, Achmad Wahidy ${ }^{2}$ \\ ${ }^{I}$ SMA Negeri 20 Palembang \\ ${ }^{2}$ Universitas PGRI Palembang \\ *Corresponding author.Email: yeti.arnila@yahoo.com
}

\begin{abstract}
The purpose of this Education study is to evaluate the significance of the effect on teacher success in SMA Negeri 20 Palembang of the main leadership style and teacher job satisfaction. This mode of analysis is quantitative descriptive by using spss program. 58 respondents with data collection techniques in the form of a questionnaire were the sample in this study. The outcomes showed that: 1) The leadership style of the principal has a major impact on teacher performance, 2) Teacher work satisfaction has a major influence on teacher results, 3) There is a major impact on teacher success between the leadership style of the principal and teacher job satisfaction. In conclusion, principal leadership and satisfaction had an impact on the teachers' performance.
\end{abstract}

Keywords: Style of leadership, Work satisfaction, Success of teachers

\section{INTRODUCTION}

The progress of a nation is determined by the quality of education of the nation as stated in the National Education System Law No. 20 of 2003 Article 3 on the functions and objectives of national education, that national education serves to develop the ability and form dignified national character and civilization in order to educate the life of the nation, as well as the goal to develop the potential of learners to become human beings who believe and fear God almighty, noble character, healthy, knowledgeable, capable, creative, independent and become a democratic and responsible citizen. [1]

Generally implemented in schools, the management of education or school management is inseparable from the model or leadership style of a principal in carrying out his role as a leader. The leadership style will be related to the results and effectiveness in leading and running the educational process in schools because the school describes the lives of small communities. This is in line with what Sagala (2012:77) says that schools are like small communities or mini-societies that become a forum for student development, not just a bureaucracy full of tasks and burdens. [2] So that the headmaster who becomes a nakoda in a sailboat must be able to steer his boat to reach the runway safely. In line with the opinion of Kartono (2010:23) the leader is a leader by initiating social behavior by organizing, directing, organizing or controlling the efforts of others or through power and position. [3] Power is the ability to direct and influence subordinates in connection with the tasks they must perform. One of the leadership models that can be used by the headmaster is the leadership model with a behavioral approach.

In addition to the headmaster's leadership pattern, other factors that influence performance include job satisfaction. Research conducted by Yasir Arafat (2016) his research revealed that 1) there is a significant influence of motivation on employee performance, 2) there is a significant influence of job satisfaction on employee performance, 3) there is a significant influence of motivation and job satisfaction together on employee performance. [4]

\section{METHODS}

According to [5], research method is basically a scientific way to obtain data with specific purposes and uses. [5] It is agreed with [6],[7],[8], [9] that research methods are a scientific way to obtain data for specific purposes. [6] The scientific method means that the research is based on scientific characteristics that are rational, empirical, and systematic. 
From both definitions, it is seen that the research method that will be done is a quantitative research of correlational type (cause and effect). Correlational type research aims to find out the existence of cause-andeffect relationships that are interconnected and related between research variables. The study consisted of three variables in the form of two free variables and one bound variable. The free variables in this study are leadership style and job satisfaction. While variables are tied to this research in the form of teacher performance in SMA Negeri 20 Palembang. The data were analysed by using SPSS 20 software program to count the correlation.

\section{RESULTS AND DISCUSSION}

\section{Table 1. Normality Test Results}

\begin{tabular}{|l|l|l|l|}
\hline Variable & $\begin{array}{l}\text { Significance } \\
\text { Value }\end{array}$ & Testing & Description \\
\hline $\begin{array}{l}\text { Leadership Style } \\
\left(\mathrm{X}_{1}\right)\end{array}$ & 0.147 & 0,05 & Normal \\
\hline $\begin{array}{l}\text { Job Satisfaction } \\
\left(\mathrm{X}_{2}\right)\end{array}$ & 0.212 & 0,05 & Normal \\
\hline $\begin{array}{l}\text { Teacher } \\
\text { Performance (Y) }\end{array}$ & 0.059 & 0,05 & Normal \\
\hline
\end{tabular}

Source: SPSS Program Processed version 20.0 Year 2020

This table explains that the significance value for leadership style variables is 0.147 , job satisfaction variable is 0.212 , and teacher performance variable is 0.059 . As it is known that if the value of significance > 0.05 then the data is distributed normally, and vice versa if the value $<0.05$ then the data does not distribute normally. Thus, the data variables of leadership style, job satisfaction, and teacher performance are distributed normally. This is due to the significance value for leadership style variables, job satisfaction, and teacher performance above 0.05 .

\section{Table 2 Homogeneity Test Results}

Test of Homogeneity of Variances

\begin{tabular}{|l|l|l|l|l|}
\hline & $\begin{array}{l}\text { Levene } \\
\text { Statistics }\end{array}$ & df1 & df2 & Sig. \\
\hline $\begin{array}{l}\text { Leadership } \\
\text { Style }\end{array}$ & 1.132 & 1 & 114 & .290 \\
\hline $\begin{array}{l}\text { Job } \\
\text { Satisfaction }\end{array}$ & 2.629 & 1 & 114 & .108 \\
\hline
\end{tabular}

Source: SPSS Program Processed version 20.0 Year 2020

The test criteria are significance value $<0.05$, then the group variant is not the same. Conversely, if the value of significance is $>0.05$, then the variant of the data group is the same. From the output, it can be seen that the significance value of the leadership style variable is $0.290>0.05$ and the value of job satisfaction significance is $0.108>0.05$. So, it can be concluded that both variables come from the same or homogeneous data.

Table 3 Double Correlation Linear Regression Test Results

\begin{tabular}{|c|c|c|c|c|c|c|}
\hline \multicolumn{6}{|c|}{ Coefficients $^{\mathrm{a}}$} & \\
\hline \multirow{2}{*}{\multicolumn{2}{|c|}{ Model }} & \multirow{2}{*}{$\begin{array}{l}\begin{array}{l}\text { Unstandardized } \\
\text { Coefficients }\end{array} \\
\text { B } \\
\end{array}$} & \multicolumn{2}{|c|}{$\begin{array}{l}\text { Standardized } \\
\text { Coefficients }\end{array}$} & \multirow[b]{2}{*}{$\mathbf{Q}$} & \multirow[b]{2}{*}{ Sig. } \\
\hline & & & $\begin{array}{l}\text { Std. } \\
\text { Error }\end{array}$ & Beta & & \\
\hline \multirow[t]{3}{*}{1} & (Constant) & $-34,719$ & 9,016 & & $-3,851$ & ,000 \\
\hline & Leadership & ,395 & ,074 & ,341 & 5,333 & \\
\hline & Satisfaction & ,993 & ,085 & ,746 & 11.660 & , 000 \\
\hline \multicolumn{7}{|c|}{ Dependent Variable: } \\
\hline
\end{tabular}

Based on the results of multiple linear regression researched on leadership style variables $\left(\mathrm{X}_{1)}\right.$ and job satisfaction $\left(\mathrm{X}_{2}\right)$ to teacher performance $(\mathrm{Y})$ can be described as follows:

$Y=-34,719+0.395 X_{1}+\mathbf{0 . 9 9 3}_{2}$

Table 4. Test Result F (Simultaneous Hypothesis)

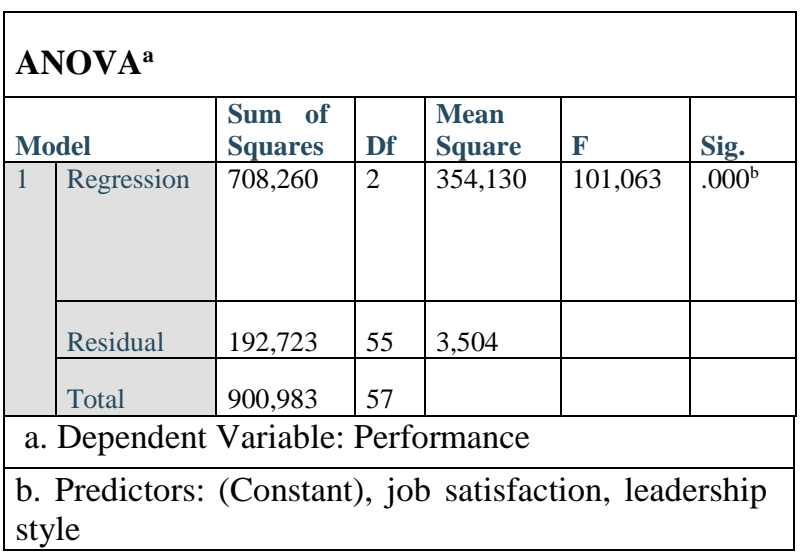

Simultaneous testing showed that the calculated $F_{\text {value }}$ was 101.063 and $F_{\text {sig was }} 0.000$ while the table $\mathrm{F}_{\text {value }}$ for $\mathrm{dk}=\mathrm{n}-2-1=58-2-1=55$ was 3.15 . That is, the calculated value $\mathrm{F}(101,063)>\mathrm{F}_{\text {table }}(3.15)$ and the value $F_{\text {sig }}(0.000)<\alpha(0.05)$, thus Ho is rejected and $\mathrm{Ha}$ is accepted. It can be explained that there is an influence of leadership style and job satisfaction on the performance of teachers in SMA Negeri 20 Palembang. 
Table 5. Test Result t (Partial Hypothesis)

\begin{tabular}{|c|c|c|c|c|c|}
\hline \multirow[b]{2}{*}{ Model } & \multicolumn{2}{|c|}{$\begin{array}{l}\text { Unstandardize } \\
\text { d Coefficients }\end{array}$} & \multirow{2}{*}{$\begin{array}{l}\text { Standardized } \\
\text { Coefficients } \\
\text { Beta }\end{array}$} & \multirow[b]{2}{*}{ Q } & \multirow[b]{2}{*}{ Sig. } \\
\hline & B & $\begin{array}{l}\text { Std. } \\
\text { Error }\end{array}$ & & & \\
\hline \begin{tabular}{l|l}
1 & (Constant) \\
\end{tabular} & $-34,719$ & 9,016 & & $-3,851$ &, 000 \\
\hline Leadership & ,395 & .074 & ,341 & 5,333 & ,000 \\
\hline $\begin{array}{l}\text { Teacher } \\
\text { Satisfaction }\end{array}$ & ,993 & .085 &, 746 & 11,600 &, 000 \\
\hline
\end{tabular}

\section{The Influence of Leadership Style on Teacher}

\section{Performance}

Based on the table of coefficients above, obtained the value $t_{\text {calculate }}$ the leadership style variable of 5,333 with the value $t_{\text {sig. }}$. By 0.000 and the value $t_{\text {table }} \mathrm{dk}=\mathrm{n}-$ $2=58-2=56$ is 1.672 . That is, the value $t$ calculate $(3,126)>t_{\text {table }}(1,672)$ and the value $t_{\text {sig }}(0.000)<\alpha$ (0.05), thus Ho is rejected and Ha is accepted. It can be explained that there is an influence of leadership style on the performance of teachers in SMA Negeri 20 Palembang. This finding is in line with [10] who found that leadership style could influence teacher performance because in leadership style, teacher learn how to lead students or people.

\section{The Effect of job satisfaction on Teacher \\ Performance}

Based on Table 4.18 above, obtained $t$ value calculates job satisfaction variable of 11,600 with $t_{\text {sigvalue }}$. That is, the value $t$ calculate $(3,126)>t_{\text {table }}$ $(1,672)$ and the value $t_{\text {sig }}(0.000)<\alpha(0.05)$, thus Ho is rejected and $\mathrm{Ha}$ is accepted. It can be explained that there is an influence of job satisfaction on the performance of teachers in SMA Negeri 20 Palembang. Result of Leadership Style Variable Determinant Coefficient $\left(\mathrm{X}_{1}\right)$

and Job Satisfaction $\left(\mathrm{X}_{2}\right)$ on Teacher Performance (Y)

\begin{tabular}{|l|l|l|l|l|}
\hline \multicolumn{2}{|l|}{ Model Summary } & $\begin{array}{l}\text { Adjusted R } \\
\text { Square }\end{array}$ & $\begin{array}{l}\text { Std. Error of } \\
\text { the Estimate }\end{array}$ \\
\hline 1 & Rodel & R Square &, 778 & 1,872 \\
\hline & $.887^{\mathrm{a}}$ &, 786 & & \\
\hline \multicolumn{7}{|l|}{ a. Predictors: (Constant), Teacher's Satisfaction, Leadership } \\
\hline
\end{tabular}

Table 6 describes the amount of correlation/relationship value (R) of 0.887 in the STRONG category. In addition, it is also explained the percentage of the influence of free variables (leadership style and job satisfaction) on bound variables (teacher performance) called coefficients of determination that are the result of the calculation of $\mathrm{R}$. From the output obtained coefficient determination (AdjustR Square) of 0.778, which contains the understanding that the influence of free variables (leadership style and job satisfaction) on bound variables (teacher performance) is $77.8 . \%$, while the remaining $22.2 \%$ is influenced by other variables that were not studied in this study.

\section{CONCLUSION}

Based on the results of data analysis, it can be concluded the following, first the leadership style has an influence on teacher performance based on the results of $t$ test analysis. This shows that there is an influence of leadership style on the performance of teachers in SMA Negeri 20 Palembang has answered the first hypothesis. Both job satisfaction has an influence on teacher performance based on the results of t test analysis. This shows that there is an influence of work complacency on the performance of teachers in SMA Negeri 20 Palembang has answered the second hypothesis. The three leadership and job satisfaction have an influence jointly on teacher performance based on the results of $t$ test analysis. This shows that there is an influence of leadership style and job satisfaction together on the performance of teachers in SMA Negeri 20 Palembang has answered the third hypothesis.

\section{REFERENCES}

[1] Law No. 20 article 3 of 2003 on the National Education System

[2] Sagala. S. (2012). Concepts and Meanings of Learning. Jakarta: Rineka Cipta

[3] Kartono. (2010). Leaders and Leadership. Jakarta: PT. King Grafindo Persada Arafat,Y. 2016. Effect of Motivation and Job Satisfaction on Employee Performance (Case Study on CV. Havraco Jaya Palembang). Prosding PPS Univrsitas PGRI Palembang. Online accessed: January 10, 2021

[5] Sugiyono. (2017). Quantitative, Qualitative and $R \& D$ Approach Education Research Method. Bandung: Alfabeta

[6] Darmadi, H. (2013). Basic Teaching Skills. Bandung: Alfabeta.

[7] Creswell, J.W. (2014). Research Design, Qualitatives, Quantitative, and Mixed. Methods Approcahes (Fourth Edition). United State of America: Sage.

[8] Sugiyono. (2014). Metode Penelitian Pendidikan Pendekatan Kuantitatif,. Kualitatif, dan R\&D. Bandung: Alfabeta.

[9] Ary, D., et al. (2010). Introduction to Research in Education. Canada. 
[10] Alimohammadi \& Neyshabor. (2013). Work motivation and organizational commitment among Iranian employees. International Journal of Research in Organizational Behavior and Human Resource Management, 1(3), 1- 12. 